\title{
Hidden Cointegration Reveals Hidden Values in Islamic Investments
}

\author{
Christos Alexakis ${ }^{1}$ \\ ESC Rennes School of Business, Department of Finance and Accounting, France \\ E-mail: christos.alexakis@,esc-rennes.com
}

\author{
Vasileios Pappas \\ School of Management, University of Bath, UK \\ E-mail: v.pappas@,bath.ac.uk
}

\author{
Alexandros Tsikouras \\ Economist \\ E-mail: alextsikouras@yahoo.com
}

\begin{abstract}
We explore long-run relationships between Islamic and conventional equity indices for the period 2000-2014. We adopt a hidden co-integration technique to decompose the series into positive and negative components; thus allowing the investigation of the indices during upward and downward markets. We find evidence of bi-directional dynamics during upward, downward and some mixed market movements. However, after adding control variables to our models, only the relationship for the negative components retains its significance; indicating that the Islamic index is the least responsive during bad times. This highlights the robust nature of Islamic investments and a possible differentiated investor reaction to financial information during market downtrends. Implications for practitioners are highlighted in a case study.
\end{abstract}

JEL Classification: G14

Keywords: Islamic equity index $\bullet$ Hidden co-integration $\bullet$ Portfolio optimisation $\bullet$ Dow Jones

Acknowledgements: We thank the participants of the $4^{\text {th }}$ Islamic Banking and Finance Conference at Lancaster University. We are grateful to an anonymous referee for the helpful comments.

${ }^{1}$ Corresponding Author e-mail: christos.alexakis@esc-rennes.com 


\section{Highlights}

We employ hidden cointegration for Islamic and conventional stock market indices

Cointegration dynamics are different for the positive, negative and cross price components

Investors may decode information differently in positive and negative markets

An Islamic Index offers risk reduction especially in negative markets 


\section{Introduction}

The Islamic finance sector has demonstrated significant resilience and growth as the landscape of financial services reshapes. With total assets around $\$ 1.8$ trillion and a strong annual growth rate, Islamic finance is quickly becoming an important part of the global financial system (EY, 2015; IMF, 2015). The global financial crisis has left the Islamic finance sector relatively untouched with a compounded annual growth around 18\% over the 2009 - 2013 period (EY, 2015). The consistent growth of the sector reassures that there is appetite for alternative, ethical investments, while increasing penetration rates for Shariah compliant products is evidenced (EY, 2015).

Islamic finance is based on a set of principles that are deeply rooted in the Islamic law (Shariah). Most common of these principles are the prohibition of interest, complex derivatives, shortselling and investments in certain prohibited business sectors such as alcohol, gambling and tobacco to name a few. Such observable features distinguish the Islamic finance sector from the rest of the financial system. From an academic viewpoint, research has sought to investigate similarities and differences between Islamic and conventional finance. Islamic banks, for instance, have been much researched in terms of business models, efficiency, financial characteristics and stability; see among others Pappas et al. (2016); Johnes et al. (2014); Abedifar et al. (2013); Beck et al. (2013); Čihák and Hesse (2010); Boumediene and Caby (2009). Most of these studies verify that the two banking systems are markedly different. Abedifar et al. (2015) provide an excellent review of the current empirical literature.

Islamic equity indices have also attracted an important chunk of the empirical research, see, for example, studies of el Alaoui et al. (2015); El Khamlichi et al. (2014); BinMahfouz and Hassan (2013) among others. However, most of the research has focused on the comparative performance of Islamic and conventional equity indices on a general basis. In the present paper we aim to investigate interrelation patterns between Islamic and conventional equity indices based on the positive and negative price components of these indices. Subsequently, we aim to uncover both performance and diversification benefits to international investors induced by the inclusion of an Islamic equity index to a well-diversified conventional portfolio.

We contribute to the extant literature in two ways. First, we provide an application of hidden co-integration technique in order to compare Islamic and conventional indices positive and negative components. In this respect, this is the first study to compare and contrast asymmetric effects in the dynamics of Islamic and conventional equity indices. Second, we provide novel empirical results by documenting the consolidation of Islamic equity indices as risk mitigation tools in the investment universe.

Our key findings may be summarised as follows. We find that the pair of positive and a pair of mixed index components are interrelated, and the dynamics of these relations are bi-directional. The negative index components are also interrelated but the dynamics are different since a unidirectional relation exists and runs from the conventional index to the Islamic. This finding indicates that the Islamic index follows the conventional in the negative components of the stock prices. In other words, it seems that the Islamic index is less responsive to bad news compared to a conventional index. This finding remains robust even when key financial variables, enter our model specification as control variables. A portfolio case study indicates 
that combining an Islamic with a conventional equity index can moderate potential stock market drops and also enhance gains in the periods of downtrends in stock prices.

The remainder of the paper is structured as follows. The relevant literature review is presented in Section 2. Sections 3 and 4 present and describe the methodology and data used. Results and discussion are presented in Section 5. Section 6 provides robustness checks with the use of control variables. Section 7 offers a portfolio case study and a final section concludes.

\section{Literature Review}

A large subset of the Islamic finance research focuses on the investigation of key financial aspects of Islamic Equity Indices (IEI). Many studies make their focal point the comparison of Islamic Equity Indices to the respective conventional ones (Ashraf \& Mohammad 2014), while others compare Islamic Equity Indices to Social and Responsible Indices (SRI) (BinMahfouz \& Hassan, 2013).

The typical focus of these comparative studies is the performance differentials between the Islamic and conventional equity indices. A priori it can be said that conventional indices should outperform Islamic Equity indices due to the fact that the latter are a subset of an unrestricted market portfolio. Nevertheless, proponents of ethical investing, which comprises Islamic Equity Indices, argue that these financial screens are merely good business practices that prevent investment in distressed companies. Hence, Islamic Equity Indices should perform better than the conventional counterparts.

The evidence from previous empirical studies of Islamic and conventional equity indices is mixed. Some studies find Islamic Equity Indices to perform better relative to conventional counterparts (Sukmana \& Kholid, 2015; Milly \& Sultan, 2012; Hussein \& Omran, 2005). Only a small number of studies find that conventional indices perform better than Islamic ones (Kok et al., 2009; Habib \& U1 Islam, 2014). Many studies fail to find any significant performance difference between the two types of indices (BinMahfouz \& Hassan, 2013; Guyot, 2011; Girard \& Hassan, 2008; Schröder, 2007; Hassan \& Girard, 2011; Hassan et al., 2005; Hakim \& Rashidian, 2004). This inconclusive evidence persists even when controlling for market sentiment. Much of the empirical evidence is supportive of the contention that Islamic Equity Indices outperform the conventional indices in times of crisis (Al-Khazali et al., 2014; Ashraf \& Mohammad, 2014). However, other studies conclude that Islamic Equity Indices underperform relative to their conventional counterparts outside of times of distress (Hussein, 2004; Hussein, 2007; Hassan \& Girard, 2011).

Due to the fact that for an investor an equity index is not directly investable unless through the use of unit trusts, mutual funds or ETFs, a number of studies have focused to the comparison of these investment vehicles. Consequently, empirical studies that compare Islamic to conventional funds (Ashraf, 2013; Rubio et al., 2012) and to Social and Responsible Funds (SRF) (Abdelsalam et al., 2014; Lyn \& Zychowicz, 2010; Forte \& Miglietta, 2011) have also appeared. Islamic funds are found to perform better (Alam \& Rajjaque, 2010; Hoepner et al., 2011; Annuar et al., 1997; Ashraf, 2013; Rubio et al. 2012) and worse (Hayat \& Kraeussl, 2011; Nainggolan, 2011; Mansor \& Bhatti, 2011) relative to conventional funds. Some studies either find no difference in the two funds' performance or the difference is sensitive to model specifications (Abderrezak, 2008; Elfakhani et al., 2007). When the sample is split to allow for 
bull and bear markets some studies conclude that Islamic funds outperform the conventional ones only during bear markets (Abdullah et al., 2007; Merdad et al., 2010); others find that Islamic funds outperform only during bull markets (Hassan \& Antoniou, 2006).

There is some criticism on a theoretical and on an empirical level whether studies on Islamic Equity Indices and Islamic Equity Funds are directly comparable. On a theoretical level, Islamic Equity Funds are more expensive to maintain as they require additional screening and monitoring for their investments to comply with the Shariah. Therefore it may be more likely that Islamic Equity Funds underperform the conventional ones. Moreover, there is evidence that investors are willing to accept a suboptimal financial performance in their ethical investments, which is not compatible with the financial performance maximisation dogma (Renneboog et al., 2008a; Renneboog et al., 2008b). On the empirical level the arguments are primarily related to several exogenous factors (i.e., fund managers skill) that could be affecting the performance. Specifically, Elfakhani et al. (2007) argue that factors such as fund priorities, benchmark selection, stock selection criteria, market timing, and evaluation horizon potentially dilute the effect of Shariah based screening. Hussein and Omran (2005) argue that the over performance of the Islamic relative to the conventional funds is due to the investment selection criteria yet it is not clear whether the fund managers exercise any additional criteria (possibly related to skill and expertise) over and above the ones stipulated under the Shariah.

Another strand of the literature has focused on the interconnection of Islamic Equity Indices to their conventional counterparts and the financial system. Theoretical arguments can be put forward according to which Islamic equity indices would be less connected to the financial markets relatively to conventional ones, mainly because of the type and financial profile of the firms they include. Empirical findings suggest that Islamic and conventional equity indices appear to be neither affected by the same risk factors nor to the same extent. For example, interest rate fluctuations have caused minimal variation in Islamic equity indices as argued in Hakim and Rashidian (2004) and el Alaoui et al. (2015). Similarly, Islamic equity indices show different behaviour following index revisions compared to conventional indices (Sadeghi, 2014). A valuable tool for portfolio diversification is therefore warranted, see for example Saiti et al. (2014) and El Khamlichi et al. (2014).

By contrast, the studies of Girard and Hassan (2008); Albaity and Ahmad (2008); Hassan and Girard (2011) find evidence in support of long-run relations between comparable Islamic and conventional equity indices, albeit El Khamlichi et al. (2014) argue that this may be sensitive to the exact methodology the index publishers follow. However, as markets become more integrated it may be expected that the two types of indices would show increasing similarities (Krasicka \& Nowak, 2012; el Alaoui et al. 2015). This is mainly attributed to the fact that Islamic equity indices become more integrated with the financial system. This can be verified by the increasing popularity of ethical investments coupled with the ever extending universe of global, regional and sectorial Islamic equity indices published by all major index companies (i.e., DJ, FTSE, MSCI). Thus, Islamic equity indices showing long-run relationships with commodity returns, which are extensively used for the asset-backed Islamic banking products (Rithuan et al. 2014), and macroeconomic variables (Hussin et al., 2013; Ibrahim, 2003) may not be out of the ordinary. Consequently any documented portfolio diversification opportunities arising from the use of Islamic Equity indices, may be washing out.

[Insert Table 1 here] 


\section{Methodology}

In this section we present the statistical methodology we adopt in the paper. We utilise the cointegration framework of Engle and Granger (1987) to test for a long-run equilibrium in two stock market indices; namely the Dow Jones Global (DJGI) and the Dow Jones Islamic Market (DJIM). Specifically, we use hidden cointegration approach and decompose the indices into positive and negative components in order to examine for possible asymmetries in line with Alexakis et al. (2013). Since cointegration implies dynamic relations between variables, we use the notion of Granger "causality" to investigate the direction of the dynamics in the examined indices.

According to cointegration theory, two series $X_{t}, Y_{t}$ which are both integrated of order one, are co-integrated if there exists a linear combination between them that is stationary, i.e integrated of order zero. The basic idea of co-integration is that series $X_{t}, Y_{t}$ move closely together without deviating one from another in the long run, even though the individual series are non-stationary.

$$
\begin{gathered}
X_{t}, Y_{t} \sim I(1) \\
z_{t}=X_{t}-a Y_{t} \\
z_{t} \sim I(0)
\end{gathered}
$$

where in $\alpha$ is the cointegrating parameter and its magnitude shows the co-integrating speed.

If two variables are cointegrated then according to the Granger Representation Theorem (Engle \& Granger, 1987), there exists a valid Error Correction Model (ECM) which is defined as:

$$
\begin{aligned}
& \Delta Y_{t}=a_{0}+\sum_{i=1}^{n} \beta_{1 i} \Delta Y_{t-i}+\sum_{i=1}^{n} \beta_{2 i} \Delta X_{t-i}+\psi_{1} z_{t-1}+\varepsilon_{1 t} \\
& \Delta X_{t}=\gamma_{0}+\sum_{i=1}^{n} \delta_{1 i} \Delta Y_{t-i}+\sum_{i=1}^{n} \delta_{2 i} \Delta X_{t-i}+\psi_{2} z_{t-1}+\varepsilon_{2 t}
\end{aligned}
$$

where $z_{t-1}$ is implicitly defined in (2), $\left|\psi_{1}\right|+\left|\psi_{2}\right| \neq 0$ and $\varepsilon_{1 t}, \varepsilon_{2 t}$ are finite moving averages.

Thus, changes in the variables $X_{t}, Y_{t}$ are partly driven by the previous value of $z_{t}$, (Granger \& Weiss, 1983). When the variables in question deviate from the steady state of equilibrium, due to some reasons such as abnormally large random disturbances or the systematic effect of a third variable which does not appear in the long run solution, the equilibrium term $z_{t-1}$ reduces this deviation and drives the variables back to the long run equilibrium. For this reason the equilibrium term $z_{t-1}$ is called error correction mechanism and is expected to have a negative sign. According to Perman (1991), the error correction term constitutes one case of a systematic disequilibrium adjustment process through which $X_{t}, Y_{t}$ are prevented from drifting apart.

Even though standard cointegration approach helps testing the temporal relationships among time series, hidden cointegration allows us to decompose the positive and negative components of each time series and, thus test for co-integration and respectively dynamic relationships in these components (Granger \& Yoon, 2002). Thus hidden cointegration allows the existence of a long run relationship only in one of the two components (i.e., during market downturns) or that the magnitude of the relationship differs between upward and downward trending markets. 
Positive and negative shocks for a pair of time series, say, $X_{t}, Y_{t}$, can be defined as:

$$
\varepsilon^{+}=\max \left(\varepsilon_{t}, d\right), \varepsilon^{-}=\min \left(\varepsilon_{t}, d\right), \eta^{+}=\max \left(\eta_{t}, d\right), \eta^{-}=\min \left(\eta_{t}, d\right)
$$

where $d$ represents a threshold value, set to zero ${ }^{2}$ in line with Alexakis et al. (2013), and $\varepsilon_{t}, \eta_{t} \sim N(0, \sigma)$

Thus, the two series $X_{t}, Y_{t}$ can then be written as cumulative sums of the positive and negative components of the two series (Granger \& Yoon, 2002).

$$
\begin{aligned}
& X_{t}=X_{t-1}+\varepsilon_{t}=X_{0}+\sum_{t=1}^{t} \varepsilon_{t}^{+}+\sum_{t=1}^{t} \varepsilon_{t}^{-} \\
& Y_{t}=Y_{t-1}+\eta_{t}=Y_{0}+\sum_{t=1}^{t} \eta_{t}^{+}+\sum_{t=1}^{t} \eta_{t}^{-}
\end{aligned}
$$

where

$$
X_{t}^{+}=\sum_{t=1}^{t} \varepsilon_{t}^{+}, X_{t}^{-}=\sum_{t=1}^{t} \varepsilon_{t}^{-}, Y_{t}^{+}=\sum_{t=1}^{t} \eta_{t}^{+}, Y_{t}^{-}=\sum_{t=1}^{t} \eta_{t}^{-}
$$

and

$$
X_{t}=X_{0}+X^{+}+X^{-}, Y_{t}=Y_{0}+Y^{+}+Y^{-}
$$

It then follows that:

$$
\Delta X_{t}^{+}=\varepsilon^{+}, \Delta X_{t}^{-}=\varepsilon^{-}, \Delta Y_{t}^{+}=\eta^{+}, \Delta Y_{t}^{-}=\eta^{-}
$$

In order to apply the hidden cointegration technique, we have to compute the first difference (e.g., $\Delta X_{t}=X_{t}-X_{t-1}$ ) for both time series $X_{t}, Y_{t}$ and then sort observations according to the sign of direction, that is, to positive and negative changes (e.g. $\Delta X_{t}^{+}, \Delta X_{t}^{-}$). Next, we calculate the cumulative sum of positive and negative changes in a specific time of period for all (four) variables (e.g., $X_{t}^{+}=\sum_{t=1}^{t} \Delta X^{+}, X_{t}^{-}=\sum_{t=1}^{t} \Delta X^{-}$). Variables $X$ and $Y$ are hidden cointegrated if their positive and negative components are cointegrated.

According to Granger and Yoon (2002), we might detect one of the following cases ${ }^{3}$ between the selected pairs of $Y$ and $X:\left\{X_{t}^{+}, Y_{t}^{+}\right\}$or $\left\{X_{t}^{-}, Y_{t}^{-}\right\}$

Case 1: Neither $\left\{X_{t}^{+}, Y_{t}^{+}\right\}$nor $\left\{X_{t}^{-}, Y_{t}^{-}\right\}$are hidden cointegrated.

\footnotetext{
${ }^{2}$ Setting the threshold variable equal to zero has the appealing interpretation that the positive and negative components are interpreted as market movements during upward and downward trending markets respectively. Other interesting choices include a risk-free rate or estimation of the threshold variable from the data; we leave these questions open to future research.

${ }^{3}$ For theoretical convenience they assumed that there is no cointegration between the positive and the negative components of the series.
} 
Case 2: Either $\left\{X_{t}^{+}, Y_{t}^{+}\right\}$or $\left\{X_{t}^{-}, Y_{t}^{-}\right\}$, but not both, are hidden cointegrated. In this case, $X$ and $Y$ are subject to positive or negative shocks.

Case 3: Both $\left\{X_{t}^{+}, Y_{t}^{+}\right\}$and $\left\{X_{t}^{-}, Y_{t}^{-}\right\}$are hidden cointegrated, but with different cointegrating vectors. In this case, the common shocks of $\mathrm{X}$ and $\mathrm{Y}$ are not cointegrated.

Case 4: Both $\left\{X_{t}^{+}, Y_{t}^{+}\right\}$and $\left\{X_{t}^{-}, Y_{t}^{-}\right\}$are hidden cointegrated. In this case, $X$ and $Y$ are cointegrated with the same cointegrating vector.

Granger and Yoon (2002) refer to the ECM emanating from the hidden cointegration as "the crouching error correction model" (CECM). In line with the aforementioned four "cases" we can derive the following CECM.

For Case 2, we assume that $\left\{X_{t}^{+}, Y_{t}^{+}\right\}$are the only components that are cointegrated with a cointegrating vector of $(1,-1)$ for convenience. Then the CECM model can be specified as:

$$
\Delta Y_{t}^{+}=\beta_{0}+\sum_{i=0}^{j 1} \beta_{1 i} \Delta Y_{t-i}^{+}+\sum_{i=0}^{j 2} \beta_{2 i} \Delta X_{t-i}^{+}+\psi_{1}\left(Y_{t-1}^{+}-X_{t-1}^{+}\right)+\xi_{1 t}
$$

and

$$
\Delta X_{t}^{+}=\delta_{0}+\sum_{i=0}^{k 1} \delta_{1 i} \Delta Y_{t-i}^{+}+\sum_{i=0}^{k 2} \delta_{2 i} \Delta X_{t-i}^{+}+\psi_{2}\left(Y_{t-1}^{+}-X_{t-1}^{+}\right)+\xi_{2 t}
$$

Alternatively, if $\left\{X_{t}^{-}, Y_{t}^{-}\right\}$are the cointegrated components, then we can derive the CECM for negative movements.

For Case 3, we conjecture that $\left\{X_{t}^{-}, Y_{t}^{-}\right\}$are the cointegrated components with a cointegrating vector of $(1,-k)$, where $k \neq 1$. Then, we have the following CECM:

$$
\begin{gathered}
\Delta X_{t}=\delta_{0}+\sum_{i=0}^{k 1} \delta_{1 i} \Delta Y_{t-i}^{-}+\sum_{i=0}^{k 2} \delta_{2 i} \Delta X_{t-i}^{-}+\sum_{i=0}^{k 3} \delta_{3 i} \Delta Y_{t-i}^{+}+ \\
\sum_{i=0}^{k 4} \delta_{4 i} \Delta X_{t-i}^{+}+\psi_{1}\left(Y_{t-1}^{+}-X_{t-1}^{+}\right)+\psi_{2}\left(Y_{t-1}^{-}-X_{t-1}^{-}\right)+\eta_{t} \\
\Delta Y_{t}=\beta_{0}+\sum_{i=0}^{j 1} \beta_{1 i} \Delta Y_{t-i}^{-}+\sum_{i=0}^{j 2} \beta_{2 i} \Delta X_{t-i}^{-}+\sum_{i=0}^{j 3} \beta_{3 i} \Delta Y_{t-i}^{+}+ \\
\sum_{i=0}^{j 4} \beta_{4 i} \Delta X_{t-i}^{+}+\rho_{1}\left(Y_{t-1}^{+}-X_{t-1}^{+}\right)+\rho_{2}\left(Y_{t-1}^{-}-X_{t-1}^{-}\right)+\xi_{t}
\end{gathered}
$$

For Case 4, we assume the existence of a common cointegrating vector $(1,-1)$ where $X$ and $Y$ have the following standard ECM: 


$$
\begin{gathered}
\delta_{0}+\sum_{i=0}^{k 1} \delta_{1 i} \Delta Y_{t-i}^{-}+\sum_{i=0}^{k 2} \delta_{2 i} \Delta X_{t-i}^{-}+\sum_{i=0}^{k 3} \delta_{3 i} \Delta Y_{t-i}^{+}+\sum_{i=0}^{k 4} \delta_{4 i} \Delta X_{t-i}^{+} \\
+\psi\left(Y_{t-1}^{+}-X_{t-1}^{+}\right)+\psi\left(Y_{t-1}^{-}-X_{t-1}^{-}\right)+\xi_{t}
\end{gathered}
$$

where $\psi=\psi_{1}=\psi_{2}$ (from Equation 14). Additionally, the coefficients of $\Delta X_{t-i}^{-}$and $\Delta X_{t-i}^{+}$ should be the same. Similarly holds for $\Delta Y_{t-i}^{-}$and $\Delta Y_{t-i}^{+}$.

Finally, for Case 1 no CECM can be derived since no pair of components is cointegrated.

\section{Data}

We consider two worldwide equity indices; one conventional and one Shariah compliant. These are the Dow Jones Global Index (DJGI) and the Dow Jones Islamic Market (DJIM) ${ }^{4}$. Our sample period spans over 1/03/2000 - 06/30/2014; a sample of 3,767 daily observations. In all cases we used the logarithmic transformation of the series. All data are sourced from Datastream.

The DJ Global Index is weighted based on float-adjusted market capitalisation, while it represents $95 \%$ of the market capitalisation of the represented countries ${ }^{5}$. Eligible for selection in the DJGI are all equities that trade in the underlying markets' major exchanges. Equities are screened for share class and liquidity, while the index is reviewed on a quarterly basis to account for de-listings, bankruptcies and M\&A activity.

The DJ Islamic Market Index applies business type and financial screening to ensure that featured equities comply with Islamic finance principles. Businesses in alcohol, tobacco and pork-related products, conventional financial services, entertainment and weapons are precluded. The main rationale behind financial screening is to ensure that companies with large elements of debt and intangible assets are excluded. Although not universally standard, financial screenings of Dow Jones ensure that equities are excluded if any of the following criteria are in excess of $33 \%$. These are: i) Total debt divided by trailing 24-month average market capitalisation; ii) Cash plus interest-bearing securities divided by trailing 24-month average market capitalisation; iii) Cash and interest-bearing securities divided by average market capitalisation; iv) Accounts receivables divided by trailing 24-month average market capitalisation. The index has been in existence since May 1999 and is reviewed quarterly.

\section{Results}

\footnotetext{
${ }^{4}$ Most of the studies that compare Islamic to conventional equity indices opt for the Dow Jones family of indices due to their longer coverage, see for example (BinMahfouz \& Hassan, 2013). A few studies have used the FTSE, MSCI, S\&P indices, see for example (El Khamlichi et al., 2014).

${ }^{5}$ The index covers the following countries: Australia, Austria, Belgium, Brazil, Canada, Chile, China, Colombia, Czech Republic, Denmark, Egypt, Finland, France, Germany, Greece, Hong Kong, Hungary, India, Indonesia, Ireland, Israel, Italy, Japan, Luxembourg, Malaysia, Mexico, Morocco, Netherlands, New Zealand, Norway, Peru, Philippines, Poland, Portugal, Qatar, Russia, Singapore, South Africa, South Korea, Spain, Sweden, Switzerland, Taiwan, Thailand, Turkey, United Arab Emirates, United Kingdom, United States.
} 
Figure 1 reports the positive and negative components of the two equity indices that are used in our analysis alongside the price and return series. Visual inspection shows that both indices have been affected by the Global Financial Crisis (GFC) and share similar dynamics.

[Figure 1 around here]

Table 2 provides key descriptive statistics for the two indices considered. Mean return is positive over the full period for both indices. Specifically, the DJGI has a mean percentage daily return of 0.0078 , while the DJIM is at 0.0074 . The annualised volatility is $16.679 \%$ for the DJGI and $20.727 \%$ for the DJIM.

[Table 2 around here]

Table 3 presents the results from the unit root tests for the indices under investigation. The results verify that the null hypothesis of a unit root is rejected using the Augmented DickeyFuller (ADF) and Philipps-Perron (PP) tests when the first difference is used.

[Table 3 around here]

Table 4 reports the ADF and PP test results for the residuals of the hidden cointegrating regressions, i.e. the regressions on the levels of the variables under investigation (equation (2) in our Methodology section). Our results show statistical evidence that the positive, the negative and a cross-component of the examined indices are cointegrated. As discussed before, according to the Granger Representation Theorem, when two series are cointegrated a valid error correction term must appear in at least one error correction equation indicating the "causality" direction.

[Table 4 around here]

In table 5 we report the results of the crouching error correction models (CECM) for the cointegrated index components (as reported in Table 4) which explore the dynamics between the Islamic and the conventional index. To accurately capture the short-run dynamics we have utilised a stepwise procedure for up to 3 lags. To account for heteroscedasticity we have used the White's robust standard errors.

[Table 5 around here]

The error correction term appears with the expected sign and is statistically significant in at least one equation of the CECM. For the positive components the error correction term appears statistically significant in both models. This statistical finding implies that between the positive components of the examined indices there exists a bi-directional dynamic relationship. For the negative components a valid and statistically significant error correction term appears only in the model where the dependent variable is the Islamic index. This indicates that the dynamics and consequently the "causality" runs from the conventional index to the Islamic index, i.e. the conventional index temporally precedes the Islamic one; hence the Islamic index has a higher resistance on market downturns. Finally, for the cross-component case the statistical results indicate a bi-directional relationship.

In our models the overall explanatory power, as this is measured by the adjusted $\mathrm{R}^{2}$, is quite low but in line with studies using stock market data of a daily frequency. Additionally, some 
lagged differenced variables proved to be statistically significant in our models. According to cointegration theory, in an error correction model the temporal "causality" can emerge from two sources: a) the sum of the coefficients of the lagged change variables which is the standard Granger test and captures the short run dynamics and b) the coefficient of the lagged error correction term, which incorporates the long run information. Theoretically though, temporal "causality" can occur through the error correction term alone.

As an approach, in an effort to explain our main statistical results, we can take the following. For the positive components of the series, observed bi-directional dynamics can be explained by the good conditions affecting both conventional and Islamic companies. Investors purchase shares of both categories not taking into account the fact that non Islamic companies may be more leveraged and more hedged with the use of derivative financial products. For the negative components of the series, it seems that the more responsive index is the conventional. Islamic companies may be slower in their reaction in declining markets since they represent companies of better financial quality, less exposed to leverage and derivatives. It seems that investors in periods of good times interpret good news catholically and they buy shares without discriminating based on financial leverage and exposure to derivatives. Nevertheless, during period of bad times investors may become more rational in economic terms and thus more reluctant to sell shares of companies which are in line with Sharia law, based primarily on the financial quality of their assets. Islamic investments during bad times are less reactive than conventional investments because in bad times it seems that financial quality matters. In this respect hidden cointegration helped us to reveal the hidden quality of Islamic investments.

\section{Robustness Checks}

As a robustness check we add some control variables to the CECM that capture the general macroeconomic environment. ${ }^{6}$ We should stress out that only macroeconomic variables of a global nature are eligible since the companies of the two equity benchmarks are geographically spread out. Hence, our choice for controls includes the logarithmic change in the oil price, as it represents one of the most widely used commodities with direct repercussions on production costs, the de-trended 7-10 years world government bond index, as a proxy for the global sovereign fixed income market, the VIX as a measure of stock market volatility and general market sentiment and the US Economic Policy Uncertainty Index (US EPUI). The US EPUI index covers over one thousand newspaper articles and identifies news related to upcoming economic uncertainty due to legislation, fiscal deficit, regulation, Federal Reserve or government reasons. All data were obtained from Datastream except the US EPUI that was obtained from its respective website. ${ }^{7}$

We utilize our stepwise procedure, in line with the main part of the paper, and Table 6 presents the results for the CECM analysis of the DJIM and DJGI indices while adding the four control variables discussed earlier. A first remark that can be made is the increase in the goodness of fit of the CECM models as evidenced by the adjusted $\mathrm{R}^{2}$. With regards to the statistical significance of the control variables, they are largely significant at the $5 \%$ across all specifications except for the variable related to the Oil which drops out of significance when the negative components are used. The statistical significance of the error correction term

\footnotetext{
${ }^{6}$ All control variables in the CECMs are transformed to be stationary.

7 The US Economic Policy Uncertainty Index can be obtained from: http://www.policyuncertainty.com/us daily.html
} 
remains only for the negative components of the series used, indicating a bi-directional relationship. However, the relationship seems to be more pronounced when the DJIM is used as a dependent variable i.e. the dynamics run stronger from the Global index to the Islamic index. Hence, the original finding that the Islamic index show a higher resistance to the market drops compared to the conventional one is maintained even when controlling for a wide set of macroeconomic characteristics. Conversely, when the positive and mixed components of the indices are used the error correction term drops out of significance indicating weak causal relationships.

[Table 6 around here]

\section{Case Study: Portfolio Optimisation}

To evaluate the relevance of our findings to practitioners we examine the benefits to portfolio diversification emanating from the use of an Islamic index during a period of good and a period of bad market conditions, in which positive and negative shocks dominate accordingly. Arguably both indices, and particularly the Dow Jones Global Index, are well-diversified portfolios leaving a small margin for improvement. Although this is not supposed to be an exhaustive experimentation of techniques and possibilities it demonstrates the diversification benefits in a clear and concise manner. We adopt the mean-variance modern portfolio theory of Markowitz (1952), albeit with a few alterations. Specifically, we allow for time-varying covariance structure among the two indices considered, similar to the study of Yilmaz (2010).

Portfolio optimisation details, in the more convenient for large portfolios matrix notation, are available in any advanced finance textbook; hence it will be mentioned here only briefly.

$$
\begin{aligned}
& \mathbf{R}=\left(\begin{array}{l}
r_{a} \\
r_{b}
\end{array}\right) \\
& \mathbf{w}=\left(\begin{array}{l}
w_{a} \\
w_{b}
\end{array}\right) \\
& \mathbf{H}=\left(\begin{array}{ll}
h_{a, t}^{2} & \\
h_{a b, t} & h_{b, t}^{2}
\end{array}\right)
\end{aligned}
$$

where $\mathbf{R}$ is a matrix with logarithmic daily returns; $\mathbf{w}$ is a matrix containing the weights assigned to each asset; $\mathbf{H}$ is a time varying variance-covariance matrix. ${ }^{8}$

Alteration of the weights would give a different return-risk composition, while the minimum variance portfolio (MVP) is the only portfolio for which no higher return may be achieved without incurring more risk. The portfolio return and risk are respectively:

$$
R_{p}^{*}=\mathbf{w}_{p}{ }^{\prime} \mathbf{R} \text { and } h_{p}^{*}=\mathbf{w}_{p}{ }^{\prime} \mathbf{H} \mathbf{w}_{p}
$$

\footnotetext{
${ }^{8}$ For the estimation of the time-varying variance covariance matrix we employ a DCC-GARCH $(1,1)$ model of Engle (2002) which combines the flexibility of the GARCH family of models at the univariate level to the lack of the dimensionality curse found in earlier multivariate frameworks, such as BEKK and VEC models.
} 
Therefore the MVP may be calculated by writing a constrained ${ }^{9}$ minimization problem and solving as:

$$
\min _{m} h_{p}^{*}=\mathbf{w}_{p}{ }^{\prime} \mathbf{H} \mathbf{w}_{p} \text { s.t. } \mathbf{w}^{\prime} 1=1
$$

To identify and allow for different market phases we use the structural breakpoint test of (Bai \& Perron, 2003) where we allow for an intercept and a linear trend to vary across the periods. The identified phases are as follows: Phase I spans from $1^{\text {st }}$ January 2000 until $21^{\text {st }}$ April 2003 and represents a downward slopping market following the dot.com crisis. Phase II is described as an upward slopping market leading to the global financial crisis pans and covers the period from $22^{\text {nd }}$ April 2003 until $2^{\text {nd }}$ August 2006. Phase III ( $3^{\text {rd }}$ August $2006-1^{\text {st }}$ October 2008) represents the initial financial turmoil related to the global financial crisis. Phase IV spans from $2^{\text {nd }}$ October 2008 until $3^{\text {rd }}$ August 2011 and its main features are the financial market deterioration and the transmission of the crisis to the macroeconomic side of the economy. A final phase (V) captures the period from $4^{\text {th }}$ October 2011 to the end of the sample where key financial markets have largely recovered from the global financial crisis. In each of the identified phases we evaluate the portfolio holdings.

Three investment strategies are tested; the first (S1) invests only in conventional equity indices (DJ Global Index), in the second (S2) only investments in Islamic equity indices are allowed (DJ Islamic Market), while the third (S3) allows for an optimal combination of both Islamic and conventional equity indices with respect to minimizing portfolio risk. Of course such strategy may not be accepted by the most religious Muslim investors as it invests in conventional assets but it could serve the diversification purposes of a conventional investor who is not interested in the religious aspect per se.

Table 7 presents the performance statistics for the three strategies in each phase. ${ }^{10}$ The average return and annualized volatility of the three investment strategies are in line with the market sentiment in each period. The pure Islamic (S2) strategy, in line with the results of the previous section, is more robust to the global financial crisis as it records around ten times lower daily losses compared to the pure conventional (S3) strategy. In the two phases following the global financial crisis (i.e., IV, V), the S2 strategy records more pronounced daily gains by around $24 \%$ and $38 \%$ respectively compared to the S1. The combined strategy (S3), particularly when adopted during financial market turmoil, can moderate the drop relative to a pure conventional strategy, while reducing the overall risk. Specifically, the S3 strategy during the global financial crisis offers a $0.3 \%$ reduction in the risk compared to a pure conventional strategy. The optimal contribution of an Islamic index to the portfolio is around $12 \%$. This reduction in risk is also evident outside a market crisis period, albeit to a smaller extent, which however highlights the merits of an Islamic equity index. Given that these two equity indices are considered as global benchmarks and feature highly traded stocks any diversification gains are expected to be marginal. However, these gains represent a low limit to the potential gain that an investor can

\footnotetext{
${ }^{9}$ The most important constraint is that the weights sum up to 1 . Other constraints may prevent negative weights (short sale) or restrict the investment in a particular asset but are not explored here.

${ }^{10} \mathrm{We}$ do not explore portfolio re-balancing in the identified periods; therefore, average returns and average conditional variances-covariances are utilized in the portfolio maximization algorithm in every period. We leave portfolio rebalancing strategies as an extension for future research.
} 
achieve from including an Islamic equity index in an investment portfolio, particularly during periods of market downtrends.

[Table 7 around here]

\section{Summary and Conclusions}

Islamic finance has been attracting rising interest during the past decade from the academic and professional world and research areas pertaining particularly to Islamic banks have received a large slice of the Islamic finance research pie. In this paper we investigate empirically the relationship between Islamic and conventional equity indices. Our motivation is to examine whether the elsewhere documented evidence on the superiority of other segments of Islamic finance (i.e. Islamic banks) materialise in the Islamic equity indices. Therefore, we compare the financial performance and the diversification benefits offered to investors of two welldiversified equity indices from the Dow Jones family; an Islamic and a conventional. We employ the novel in the area, hidden co-integration technique along with the crouching error correction models.

Our results show statistical evidence that positive, negative and some mixed components of the examined indices are cointegrated. For the positive and mixed components we obtain statistical evidence for bi-directional "causality", while for the negative components the "causality" runs from the conventional index to the Islamic, in the sense that the conventional index temporally precedes the Islamic one. When we use a set of possible control variables in our CECMs, the cointegration dynamics appeared statistically significant only for the negative component of the variables under investigation.

In an effort to explain the main statistical results we may argue that the possible bi-directional dynamics for the positive component can be explained by a kind of holistic reaction of investors to good market conditions affecting both conventional and Islamic companies. Investors are likely to purchase shares with little analysis on the fundamentals of the companies represented by the two indices. The fact that non-Islamic companies may have higher leverage and financial exposure owing, in part, to the use of financial derivatives, whereas such practices are shunned in Islamic finance, does not appear to affect the investment behaviour during market uptrends. Conversely, for the negative components of the series, it seems that the more responsive index is the conventional. Islamic companies are slower in stock price drops during declining markets, which may plausibly be attributed their superior financial quality. During bad market times investors may become more rational in economic terms, evaluate fundamentals differently (i.e., give more attention to leverage ratios), and are thus more reluctant to sell shares of companies which are in line with Sharia law, based primarily on the financial quality of their assets. It seems here that we evidence an asymmetry in investors' reaction for profits and losses. This reaction has been reported widely in economics and the explanation is based primarily on patterns of behavioural finance. The reflection effect, reported by Kahneman and Tversky (1979), is a classic example where investors change their attitude toward risk when there is a shift from gains to equal amounts of losses. Islamic investments during bad times are less reactive than conventional investments because in bad times financial quality possibly matters in investors' minds. 
As a practitioners implication of our findings we perform a portfolio diversification analysis during up-market and down-market periods and assess the benefits from optimally combining an Islamic and a conventional equity index. Our findings suggest that the inclusion of an Islamic index in a conventional portfolio can offer a valuable reduction in investor risk, particularly during periods of downtrends.

Directions for future research may include the investigation of individual share prices as well as trading volume for Islamic and non-Islamic companies. In this direction we may better understand the role of religious and ethnical characteristics as well as general human behaviour in financial decision making. We will pursue some of these avenues in future research.

\section{References}

Abdelsalam, O., Fethi, M. D., Matallín, J. C., \& Tortosa-Ausina, E. (2014). On the Comparative Performance of Socially Responsible and Islamic Mutual Funds. Journal of Economic Behavior and Organization, 103, 108-128. http://doi.org/10.1016/j.jebo.2013.06.011

Abderrezak, F. (2008). The Performance of Islamic Equity Funds: A Comparison to Conventional, Islamic, and Ethical Benchmarks. University of Maastricht.

Abdullah, F., Hassan, T., \& Mohamad, S. (2007). Investigation of Performance of Malaysian Islamic Unit Trust Funds: Comparison with Conventional Unit Trust Funds. Managerial Finance, 33(2), 142-153. http://doi.org/10.1108/03074350710715854

Abedifar, P., Ebrahim, S. M., Molyneux, P., \& Tarazi, A. (2015). Islamic Banking and Finance: Recent Empirical Literature and Directions for Future Research. Journal of Economic Surveys, 29(4), 637-670. http://doi.org/10.1111/joes.12113

Abedifar, P., Molyneux, P., \& Tarazi, A. (2013). Risk in Islamic Banking. Review of Finance, 17 (6), 2035-2096. http://doi.org/10.1093/rof/rfs041

Alam, N., \& Rajjaque, M. S. (2010). Shariah-Compliant Equities: Empirical Evaluation of Performance in the European Market during Credit Crunch. Journal of Financial Services Marketing, 15(3), 228-240. http://doi.org/10.1057/fsm.2010.19

Albaity, M., \& Ahmad, R. (2008). Performance of Syariah and Composite Indices: Evidence from Bursa Malaysia. Asian Academy of Management: Journal of Accounting and Finance, 4(1), 23-43.

Alexakis, C., Dasilas, A., \& Grose, C. (2013). Asymmetric Dynamic Relations between Stock Prices and Mutual Fund Units in Japan. An Application of Hidden Cointegration Technique. International Review of Financial Analysis, 28, 1-8. http://doi.org/10.1016/j.irfa.2013.02.001

Al-Khazali, O., Lean, H. H., \& Samet, A. (2014). Do Islamic Stock Indexes Outperform Conventional Stock Indexes? A Stochastic Dominance Approach. Pacific Basin Finance Journal, 28, 29-46. http://doi.org/10.1016/j.pacfin.2013.09.003 
Annuar, M. N., Shamsher, M., Ngu, M. H. (1997). Selectivity and Timing: Evidence from the Performance of Malaysian Unit Trusts. Pertanika Journal of Social Sciences \& Humanities 5, 45-57.

Ashraf, D. (2013). Performance Evaluation of Islamic Mutual Funds relative to Conventional Funds: Empirical Evidence from Saudi Arabia. International Journal of Islamic and Middle Eastern Finance and Management, 6(2), 105-121. http://doi.org/10.1108/17538391311329815

Ashraf, D., \& Mohammad, N. (2014). Matching Perception with the Reality-Performance of Islamic Equity Investments. Pacific Basin Finance Journal, 28, 175-189. http://doi.org/10.1016/j.pacfin.2013.12.005

Bai, J., \& Perron, P. (2003). Computation and Analysis of Multiple Structural Change Models. Journal of Applied Econometrics, 18, 1-22.

Beck, T., Demirgüç-Kunt, A., \& Merrouche, O. (2013). Islamic vs. Conventional Banking: Business Model, Efficiency and Stability. Journal of Banking and Finance, 37(2), 433447. http://doi.org/10.1016/j.jbankfin.2012.09.016

BinMahfouz, S., \& Hassan, M. K. (2013). Sustainable and Socially Responsible Investing: Does Islamic Investing Make a Difference? Humanomics, 29(3), 164-186. http://doi.org/10.1108/H-07-2013-0043

Boumediene, A., \& Caby, J. (2009). The Stability of Islamic Banks during the Subprime Crisis. SSRN Electronic Journal. http://doi.org/10.2139/ssrn.1524775

Čihák, M., \& Hesse, H. (2010). Islamic Banks and Financial Stability: An Empirical Analysis. Journal of Financial Services Research, 38, 95-113. http://doi.org/10.1007/s10693-0100089-0

el Alaoui, A. O., Dewandaru, G., Azhar Rosly, S., \& Masih, M. (2015). Linkages and CoMovement between International Stock Market Returns: Case of Dow Jones Islamic Dubai Financial Market Index. Journal of International Financial Markets, Institutions and Money, 36, 53-70. http://doi.org/10.1016/j.intfin.2014.12.004

El Khamlichi, A., Sarkar, K., Arouri, M., \& Teulon, F. (2014). Are Islamic Equity Indices More Efficient than their Conventional Counterparts? Evidence from Major Global Index Families. Journal of Applied Business Research, 30(4), 1137-1150.

Elfakhani, S., Hassan, K., \& Sidani, Y. (2007). Islamic Mutual Funds. In Hassan, K. \& Lewis, M., Eds. Handbook of Islamic Banking. Edward Elgar, pp. 253-273.

Engle, R. (2002). Dynamic Conditional Correlation. Journal of Business \& Economic Statistics, 20(3), 339-350. http://doi.org/10.1198/073500102288618487

Engle, R. F., \& Granger, C. W. J. (1987). Co-Integration and Error Correction: Representation, Estimation, and Testing. Econometrica, 55(2), 251-276.

EY. (2015). World Islamic Banking Competitiveness Report 2014-15. Ernst \& Young Marketing Business. 
Forte, G., \& Miglietta, F. (2011). A Comparison of Socially Responsible and Islamic Equity Investments. Journal of Money, Investment and Banking, 21, 116-132.

Girard, E. C., \& Hassan, M. K. (2008). Is There a Cost to Faith-Based Investing: Evidence from FTSE Islamic Indices. The Journal of Investing, 17(4), pp.112-121.

Granger, C., \& Weiss, A. (1983). Time Series Analysis of Error-Correction Models. In Karlin, S., Amemiya, T., and Goodman. L. A. (Eds.), Studies in Econometrics, Time Series and Multivariate Statistics, New York: Academic Press, pp. 255-278.

Granger, C., \& Yoon, G. (2002). Hidden Cointegration. Department of Economics, University of California, San Diego. Unpublished Working Paper.

Guyot, A. (2011). Efficiency and Dynamics of Islamic Investment: Evidence of Geopolitical Effects on Dow Jones Islamic Market Indexes. Emerging Markets Finance and Trade, 47(6), 24-45. http://doi.org/10.2753/REE1540-496X470602

Habib, M., \& Ul Islam, K. (2014). Performance of Shariah Compliant Index: A Comparative Study of India and Malaysia. International Journal of Interdisciplinary and Multidisciplinary Studies, 1(6), 231-240.

Hakim, S. \& Rashidian, M. (2004). Risk and Return of Islamic Stock Market Indexes. Paper presented at the International Seminar of Nonbank Financial Institutions: Islamic Alternatives, Kuala Lumpur, Malaysia.

Hassan, A., \& Antoniou, A. (2006). Equity Fund's Islamic Screening: Effects on its Financial Performance. In Ali, S. S. \& Ahmad, A. (Eds.), Islamic Banking and Finance: Fundamentals and Contemporary Issues, Jeddah, Saudi Arabia: IRTI, pp. 197-214.

Hassan, A., Antoniou, A., \& Paudyal, D. K. (2005). Impact of Ethical Screening on Investment Performance: The Case of Dow Jones Islamic Index. Islamic Economic Studies, 12(2), 67-97.

Hassan, K., \& Girard, E. (2011). Faith-Based Ethical Investing: The Case of Dow Jones Islamic Indexes. Working Paper 2011-WP-05. Network Financial Institute, Indiana State University, Indiana.

Hayat, R., \& Kraeussl, R. (2011). Risk and Return Characteristics of Islamic Equity Funds. Emerging Markets Review, 12(2), 189-203. http://doi.org/10.1016/j.ememar.2011.02.002

Hoepner, A. G. F., Hussain, G. R., \& Rezec, M. (2011). Islamic Mutual Funds' Financial Performance and International Investment Style: Evidence from 20 Countries. European Journal of Finance, 17(9-10), 828-850. http://doi.org/10.1080/1351847X.2010.538521

Hussein, K. (2004). Ethical Investment: Empirical Evidence from FTSE Islamic Index. Islamic Economic Studies, 12(1), 21-40.

Hussein, K., \& Omran, M. (2005). Ethical Investment Revisited: Evidence from Dow Jones Islamic Indexes. The Journal of Investing, 14(3), 105-126.

Hussein. K. (2007). Islamic Investment: Evidence from Dow Jones and FTSE Indices. In Iqbal, M., Ali, S.S., Muljawan, D. (Eds.), Advances in Islamic Economics and Finance, Vol 1, Islamic Research and Training Institute, Jeddah, KSA, pp. 387-401 
Hussin, M., Muhammad, F., Razak, A. A., Gan Pei, T., \& Nurfakhzan, M. (2013). The Link between Gold Price, Oil Price and Islamic Stock Market: Experience from Malaysia. Journal of Studies in Social Sciences, 4(2), 161-182.

Ibrahim, M. (2003). Macroeconomic Forces and Capital Market Integration: A VAR Analysis for Malaysia. Journal of the Asia Pacific Economy, 8(1), 19-40. http://doi.org/10.1080/1354786032000045228

IMF. (2015) Islamic Finance and the Role of the IMF. http://www.imf.org/external/themes /islamicfinance/\#Factsheet Accessed 15 April 2015

Johnes, J., Izzeldin, M., \& Pappas, V. (2014). A Comparison of Performance of Islamic and Conventional Banks 2004-2009. Journal of Economic Behavior and Organization, 103(Supplement), 93-107. http://doi.org/10.1016/j.jebo.2013.07.016

Kahneman, D., \& Tversky, A. (1979). Prospect Theory: An Analysis of Decision under Risk. Econometrica, 47(2), 263-292.

Kok, S., Giorgioni, G., \& Laws, J. (2009). Performance of Shariah-Compliant Indices in London and NY Stock Markets and their Potential for Diversification. International Journal of Monetary Economics and Finance, 2(3/4), 398-408. http://doi.org/10.1504/IJMEF.2009.029071

Krasicka, O., \& Novak, S. (2012). What's in It for Me? A Primer on Differences between Islamic and Conventional Finance in Malaysia. IMF Working Paper. http://doi.org/10.5089/9781475504224.001

Lyn, E. O., \& Zychowicz, E. J. (2010). The Impact of Faith-Based Screens on Investment Performance. The Journal of Investing, 19(3), 136-143.

Mansor, F., \& Bhatti, M. I. (2011). Risk and Return Analysis on Performance of the Islamic Mutual Funds : Evidence from Malaysia. Global Economy and Finance Journal, 4(1), 1931 .

Markowitz, H. (1952). Portfolio Selection. The Journal of Finance, 7(1), 77-91.

Merdad, H., Hasan, M., \& Alhenawi, Y. (2010). Islamic versus Conventional Mutual Funds' Performance in Saudi Arabia: A Case Study. Islamic Economics, 23(2), 157-193.

Milly, M. \& Sultan, J., (2012). Portfolio Diversification during Financial Crisis: Analysis of Faith-Based Investment Strategies. In Building Bridges Across the Financial Communities: The Global Financial Crisis, Social Responsibility, and Faith-based Finance. Harvard Law School, pp. 334-352.

Nainggolan, Y. A. (2011). Taking a Leap of Faith: Are Investors Left Short Changed? Queensland University of Technology.

Pappas, V., Ongena, S., Izzeldin, M., \& Fuertes, A.-M. (2016). A Survival Analysis of Islamic and Conventional Banks. Journal of Financial Services Research, 1-36. http://doi.org/10.1007/s10693-016-0239-0

Perman, R. (1991). Cointegration: An Introduction to the Literature. Journal of Economic Studies, 18(3), 3-33. 
Renneboog, L., Ter Horst, J., \& Zhang, C. (2008a). The Price of Ethics and Stakeholder Governance: The Performance of Socially Responsible Mutual Funds. Journal of Corporate Finance, 14(3), 302-322. http://doi.org/10.1016/j.jcorpfin.2008.03.009

Renneboog, L., Ter Horst, J., \& Zhang, C. (2008b). Socially Responsible Investments: Institutional Aspects, Performance, and Investor Behavior. Journal of Banking and Finance, 32(9), 1723-1742. http://doi.org/10.1016/j.jbankfin.2007.12.039

Rithuan, S., Abdullah, A., \& Masih, A. (2014). The Impact of Crude Oil Price on Islamic Stock Indices of Gulf Cooperation Council (GCC) Countries: A Comparative Analysis. MPRA Working Paper.

Rubio, J. F., Hassan, M. K., \& Merdad, H. J. (2012). Non-Parametric Performance Measurement of International and Islamic Mutual Funds. Accounting Research Journal, 25(3), 208-226. http://doi.org/10.1108/10309611211290176

Sadeghi, M. (2014). Are Faithful Investors Rewarded by the Market Place? Evidence from Australian Shariah-Compliant Equities. International Review of Business Research Papers, 10(2), 160-177.

Saiti, B., Bacha, O., \& Masih, M. (2014). The Diversification Benefits from Islamic Investment during the Financial Turmoil: The case for the US-Based Equity Investors. Borsa Istanbul Review, 14(4), 196-211.

Schröder, M. (2007). Is there a Difference? The Performance Characteristics of SRI Equity Indices. Journal of Business Finance \& Accounting, 34(1-2), 331-348.

Sukmana, R., \& Kholid, M. (2015). Impact of Global Financial Crisis on Islamic and Conventional Stocks in Emerging Market: An Application of ARCH and GARCH Method. Asian Academy of Management Journal of Accounting \& Finance.

Yilmaz, T. (2010). Improving Portfolio Optimization by DCC and DECO GARCH: Evidence from Istanbul Stock Exchange. MPRA Paper No. 27314. 
Table 1. Studies on Islamic Equity Indices and Islamic Equity Funds.

\begin{tabular}{lll}
\hline Context & Focus & Studies \\
\hline \multicolumn{2}{l}{ Performance comparative studies between Islamic and conventional equity indices } \\
\hline \multicolumn{2}{l}{ Islamic equity indices outperform conventional equity indices } & \\
& Indonesia & Sukmana and Kolid (2012) \\
Global & Milly and Sultan (2012) \\
Global & Malaysia & Hussein and Omran (2005) \\
Islamic equity indices underperform conventional equity indices & \\
Global & Kok et al. (2009) \\
India & Habib and Ul-islam (2014) \\
No difference between Islamic and conventional equity indices & \\
Global & Hassan and Girard (2011) \\
Global & Schröder (2007) \\
Regional & Guyot (2011) \\
Global & Hakim and Rashidian (2004) \\
Global & Binmahfouz and Hassan (2013) \\
Global & Hassan et al. (2005) \\
Global & Girard and Hassan (2008)
\end{tabular}

Islamic equity indices outperform conventional equity indices during bear markets
Regional/Global
Ashraf and Mohammad (2014)
Regional/Global
Al-Khazali et al. (2014)

Islamic equity indices underperform conventional equity indices during bull markets

$$
\begin{array}{ll}
\text { Global } & \text { Hussein }(2004,2007) \\
\text { Global } & \text { Hassan and Girard (2011) }
\end{array}
$$

\begin{tabular}{ll}
\hline \multicolumn{2}{l}{ Performance comparative studies between Islamic and conventional equity funds } \\
\hline \multicolumn{2}{l}{ Islamic equity funds outperform conventional equity funds } \\
Global & Hoepner et al. (2011) \\
Saudi Arabia & Ashraf (2013) \\
Global & Rubio (2012) \\
Malaysia & Annuar et al. (1997) \\
Europe & Alam and Rajjaque (2010) \\
& \\
Islamic equity funds underperform conventional equity funds & \\
Global & Hayat and Kraeussl (2011) \\
Global & Nainggolan (2011) \\
Malaysia & Mansor and Bhatti (2011)
\end{tabular}

No difference between Islamic and conventional equity funds

$$
\begin{array}{ll}
\text { Global } & \text { Abderrezak (2008) } \\
\text { Global } & \text { Elfakhani et al. (2007) }
\end{array}
$$

Islamic equity funds outperform conventional equity funds during bear markets

$\begin{array}{ll}\text { Malaysia } & \text { Abdullah et al. (2007) } \\ \text { Saudi Arabia } & \text { Merdad et al. (2010) }\end{array}$

Islamic equity funds outperform conventional equity funds during bull markets 
Table 2. Descriptive Statistics.

\begin{tabular}{lcccrrr}
\hline & Mean & Maximum & Minimum & Volatility & Skewness & Kurtosis \\
\hline Dow Jones Islamic Market & 0.0074 & 11.740 & -9.697 & 20.727 & -0.045 & 9.848 \\
Dow Jones Global Market & 0.0078 & 8.664 & -7.160 & 16.679 & -0.359 & 9.961 \\
\hline \multicolumn{2}{l}{ Notes: The table reports key descriptive statistics for the percentage returns of the two equity indices over the sample period. Volatility refers to the percentage }
\end{tabular}

Notes: The table reports key descriptive statistics for the percentage returns of the two equity indices over the sample period. Volatility refers to the percentage annualised volatility. ${ }^{* * * * * *}$ denote statistical significance at the $10 \%, 5 \%$ and $1 \%$ levels respectively. 
Table 3. Unit root tests of the series.

\begin{tabular}{lcc}
\hline & ADF statistic & PP statistic \\
\hline Dow Jones Islamic Market & -0.210 & -0.217 \\
Dow Jones Global Market & -0.832 & -0.797 \\
First differences in Dow Jones Islamic Market & $-11.362^{* * *}$ & $-65.690^{* * *}$ \\
First differences in Dow Jones Global Market & $-14.073^{* * *}$ & $-51.777^{* * *}$ \\
\hline Notes: ADF and PP denote the Augmented Dickey-Fuller and Phillips-Perron unit root tests respectively. ${ }^{* * * * * * *}$ denote statistical significance at the \\
$10 \%, 5 \%$ and $1 \%$ levels respectively.
\end{tabular}


Table 4. Hidden Cointegration tests.

\begin{tabular}{llll}
\hline Dependent variable & Independent variable & ADF statistic & PP statistic \\
\hline$D J G I^{+}$ & $D J I M^{+}$ & $-3.949^{* * *}$ & $-7.009^{* * *}$ \\
$D J I M^{+}$ & $D J G I^{+}$ & $-4.253^{* * *}$ & $-7.545^{* * *}$ \\
$D J G I^{-}$ & $D J I M^{-}$ & $-3.531^{* * *}$ & $-5.335^{* * *}$ \\
$D J I M^{-}$ & $D J G I^{-}$ & $-4.047^{* * *}$ & $-6.133^{* * *}$ \\
$D J G I^{+}$ & $D J I M^{-}$ & $-3.181^{* *}$ & $-3.373^{* *}$ \\
$D J I M^{+}$ & $D J G I^{-}$ & -2.394 & -2.387 \\
$D J G I^{-}$ & $D J I M^{+}$ & -2.302 & -2.293 \\
$D J I M^{-}$ & $D J G I^{+}$ & $-3.585^{* * *}$ & $-3.858^{* * *}$ \\
\hline Notes: The table reports the Augmented Dickey Fuller and Phillips-Perron statistics for the residuals of the hidden cointegration models. The
\end{tabular}

Notes: The table reports the Augmented Dickey Fuller and Phillips-Perron statistics for the residuals of the hidden cointegration models. The positive and negative superscripts denote the positive and negative components of the indices respectively. ${ }^{*},{ }^{* *},{ }^{* * *}$ denote statistical significance at the $10 \%, 5 \%$ and $1 \%$ levels respectively. 
Table 5. Results from the crouching error correction model (CECM) for the indices.

\begin{tabular}{|c|c|c|c|c|c|}
\hline Variable & Estimate & t-statistic & Variable & Estimate & t-statistic \\
\hline Dependent value: $\Delta(D J G I)^{+}$ & & & Dependent value: $\Delta(D J I M)^{+}$ & & \\
\hline Constant & $0.003^{* * *}$ & 20.091 & Constant & $0.004^{* * *}$ & 23.685 \\
\hline$E C T_{t-1}$ & $-0.001^{* * *}$ & -2.848 & $E C T_{t-1}$ & $-0.001^{* *}$ & -2.005 \\
\hline$\Delta(D J I M)_{t-2}^{+}$ & $0.042^{* * *}$ & 3.191 & $\Delta(D J I M)_{t-2}^{+}$ & $0.029^{*}$ & 1.768 \\
\hline$\Delta(D J I M)_{t-3}^{+}$ & $0.063^{* * *}$ & 2.928 & $\Delta(D J I M)_{t-3}^{+}$ & $0.138^{* * *}$ & 4.898 \\
\hline$\Delta(D J G I)_{t-1}^{+}$ & $-0.077^{* * *}$ & -2.587 & $\Delta(D J G I)_{t-1}^{+}$ & $-0.059^{* * *}$ & -2.794 \\
\hline$\Delta(D J G I)_{t-2}^{+}$ & - & - & $\Delta(D J G I)_{t-2}^{+}$ & - & - \\
\hline $\mathrm{R}^{2}$-adjusted & 0.035 & & $\mathrm{R}^{2}$-adjusted & 0.011 & \\
\hline Dependent value: $\Delta(D J G I)^{-}$ & & & Dependent value: $\Delta(D J I M)^{-}$ & & \\
\hline Constant & $-0.002^{* * *}$ & -14.712 & Constant & $-0.003^{* * *}$ & -18.469 \\
\hline$E C T_{t-1}$ & -0.001 & -0.704 & $E C T_{t-1}$ & $-0.001^{* * *}$ & -3.617 \\
\hline$\Delta(D J I M)_{t-1}^{-}$ & $0.184^{* * *}$ & 14.191 & $\Delta(D J I M)_{t-1}^{-}$ & - & - \\
\hline$\Delta(D J I M)_{t-2}^{-}$ & $0.070^{* * *}$ & 5.372 & $\Delta(D J I M)_{t-2}^{-}$ & $0.153^{* * *}$ & 4.957 \\
\hline$\Delta(D J I M)_{t-3}^{-}$ & - & - & $\Delta(D J I M)_{t-3}^{-}$ & - & - \\
\hline$\Delta(D J G I)_{t-2}^{-}$ & - & - & $\Delta(D J G I)_{t-2}^{-}$ & $-0.082^{* *}$ & -2.142 \\
\hline$\Delta(D J G I)_{t-3}^{-}$ & $0.116^{* * *}$ & 7.390 & $\Delta(D J G I)_{t-3}^{-}$ & $0.165^{* * *}$ & 8.142 \\
\hline $\mathrm{R}^{2}$-adjusted & 0.081 & & $\mathrm{R}^{2}$-adjusted & 0.042 & \\
\hline Dependent value: $\Delta(D J G I)^{+}$ & & & Dependent value: $\Delta(D J I M)^{-}$ & & \\
\hline Constant & $0.002^{* * *}$ & 12.368 & Constant & $-0.002^{* * *}$ & -9.138 \\
\hline$E C T_{t-1}$ & $-0.001^{* * *}$ & -4.237 & $E C T_{t-1}$ & $-0.001^{* *}$ & -2.013 \\
\hline$\Delta(D J I M)_{t-1}^{-}$ & $0.031^{* *}$ & 2.430 & $\Delta(D J I M)_{t-1}^{-}$ & $0.066^{* * *}$ & 3.808 \\
\hline$\Delta(D J I M)_{t-2}^{-}$ & $-0.138^{* * *}$ & -11.141 & $\Delta(D J I M)_{t-2}^{-}$ & $0.147^{* * *}$ & 8.678 \\
\hline$\Delta(D J I M)_{t-3}^{-}$ & $-0.099^{* * *}$ & -7.693 & $\Delta(D J I M)_{t-3}^{-}$ & $0.103^{* * *}$ & 5.920 \\
\hline$\Delta(D J G I)_{t-1}^{+}$ & $0.085^{* * *}$ & 4.927 & $\Delta(D J G I)_{t-1}^{+}$ & $-0.051^{* *}$ & -2.169 \\
\hline$\Delta(D J G I)_{t-2}^{+}$ & $0.072^{* * *}$ & 4.239 & $\Delta(D J G I)_{t-2}^{+-1}$ & $-0.147^{* * *}$ & -6.408 \\
\hline$\Delta(D J G I)_{t-3}^{+}$ & $0.038^{* *}$ & 2.274 & $\Delta(D J G I)_{t-3}^{+}$ & $-0.058^{* *}$ & -2.532 \\
\hline $\mathrm{R}^{2}$-adjusted & 0.071 & & $\mathrm{R}^{2}$-adjusted & 0.048 & \\
\hline
\end{tabular}


Notes: DJGI and DJIM denote the Dow Jones Global and the Dow Jones Islamic Market indices respectively. ECT denotes the Error Correction Term. $\Delta(\bullet)$ is the first difference operator. ${ }^{*},{ }^{* *},{ }^{* * *}$ denote statistical significance at the $10 \%, 5 \%$ and $1 \%$ levels respectively. - denotes a variable that the stepwise procedure dropped due to not being statistically

significant at the minimum of $10 \%$. 
Table 6. Results from the conditional crouching error correction model (CECM) for the indices.

\begin{tabular}{|c|c|c|c|c|c|}
\hline Variable & Estimate & t-statistic & Variable & Estimate & t-statistic \\
\hline Dependent value: $\Delta(D J G I)^{+}$ & & & Dependent value: $\Delta(D J I M)^{+}$ & & \\
\hline Constant & $-0.0012^{* * *}$ & -3.7497 & Constant & $-0.0015^{* * *}$ & -4.0544 \\
\hline$E C T_{t-1}$ & -0.0008 & -1.2127 & $E C T_{t-1}$ & -0.0012 & -1.5951 \\
\hline$W G B I_{t-2}$ & $-0.0063^{* *}$ & -2.3983 & $W G B I_{t-2}$ & - & - \\
\hline$W G B I_{t-3}$ & - & - & $W G B I_{t-3}$ & $-0.0077^{* *}$ & -2.4981 \\
\hline$\Delta O i l_{t-1}$ & - & - & $\Delta O i l_{t-1}$ & - & - \\
\hline$\Delta O i l_{t-2}$ & $-0.0092^{*}$ & -1.8644 & $\Delta O i l_{t-2}$ & - & - \\
\hline$V I X_{t-1}$ & $0.0006^{* * *}$ & 7.2958 & $V I X_{t-1}$ & $0.0010^{* * *}$ & 9.7857 \\
\hline$V I X_{t-2}$ & - & - & $V I X_{t-2}$ & - & - \\
\hline$V I X_{t-3}$ & $-0.0004^{* * *}$ & -5.0613 & $V I X_{t-3}$ & $-0.0008^{* * *}$ & -7.3245 \\
\hline$U S E P U I_{t-1}$ & $0.0033^{*}$ & 1.7895 & $U S E P U I_{t-1}$ & $0.0053^{* *}$ & 2.4221 \\
\hline$U S E P U I_{t-2}$ & - & - & $U S E P U I_{t-2}$ & - & - \\
\hline$U S E P U I_{t-3}$ & - & - & $U S E P U I_{t-3}$ & - & - \\
\hline$\Delta(D J G I)_{t-1}^{+}$ & - & - & $\Delta(D J G I)_{t-1}^{+}$ & - & - \\
\hline$\Delta(D J G I)_{t-2}^{+}$ & - & - & $\Delta(D J G I)_{t-2}^{+}$ & - & - \\
\hline$\Delta(D J I M)_{t-1}^{+}$ & $0.0789^{* * *}$ & 4.8211 & $\Delta(D J I M)_{t-1}^{+}$ & $-0.1516^{* * *}$ & -7.8812 \\
\hline$\Delta(D J I M)_{t-2}^{+}$ & - & - & $\Delta(D J I M)_{t-2}^{+}$ & - & - \\
\hline$\Delta(D J I M)_{t-3}^{+}$ & - & - & $\Delta(D J I M)_{t-3}^{+}$ & $0.1774^{* * *}$ & 5.5232 \\
\hline $\mathrm{R}^{2}$-adjusted & 0.1210 & & $\mathrm{R}^{2}$-adjusted & 0.1264 & \\
\hline Dependent value: $\Delta(D J G I)^{-}$ & & & Dependent value: $\Delta(D J I M)^{-}$ & & \\
\hline Constant & $0.0013^{* * *}$ & 3.6201 & Constant & $0.0015^{* * *}$ & 3.7165 \\
\hline$E C T_{t-1}$ & $-0.0016^{* * *}$ & -3.1316 & $E C T_{t-1}$ & $-0.0020^{* * *}$ & -3.7447 \\
\hline$W G B I_{t-1}$ & - & - & $W G B I_{t-1}$ & - & - \\
\hline$W G B I_{t-2}$ & - & - & $W G B I_{t-2}$ & - & - \\
\hline$W G B I_{t-3}$ & $0.0062^{* *}$ & 2.0663 & $W G B I_{t-3}$ & $0.0093^{* * *}$ & 2.7382 \\
\hline$\Delta O i l_{t-1}$ & - & - & $\Delta O i l_{t-1}$ & - & - \\
\hline$\Delta O i l_{t-2}$ & - & - & $\Delta O i l_{t-2}$ & - & - \\
\hline$\Delta O i l_{t-3}$ & $0.0211^{* * *}$ & 3.7965 & $\Delta O i l_{t-3}$ & $0.0214^{* * *}$ & 3.3957 \\
\hline$V I X_{t-1}$ & $-0.0004^{* * *}$ & -2.9998 & $V I X_{t-1}$ & -0.0002 & -1.0067 \\
\hline
\end{tabular}




\begin{tabular}{|c|c|c|c|c|c|}
\hline$V I X_{t-2}$ & $0.0008^{* * *}$ & 3.8023 & $V I X_{t-2}$ & $0.0007^{* * * *}$ & 2.3530 \\
\hline$V I X_{t-3}$ & $-0.0005^{* * *}$ & -3.1242 & $V I X_{t-3}$ & $-0.0006^{* * *}$ & -3.0898 \\
\hline$U S E P U I_{t-1}$ & - & - & $U S E P U I_{t-1}$ & - & - \\
\hline$U S E P U I_{t-2}$ & - & - & $U S E P U I_{t-2}$ & - & - \\
\hline$U S E P U I_{t-3}$ & $-0.0138^{* * *}$ & -6.6249 & $U S E P U I_{t-3}$ & $-0.0160^{* * *}$ & -6.8073 \\
\hline$\Delta(D J G I)_{t-1}^{-}$ & - & - & $\Delta(D J G I)_{t-1}^{-}$ & - & - \\
\hline$\Delta(D J G I)_{t-2}^{-}$ & - & - & $\Delta(D J G I)_{t-2}^{-}$ & - & - \\
\hline$\Delta(D J G I)_{t-3}^{-}$ & $0.1291^{* * *}$ & 5.3248 & $\Delta(D J G I)_{t-3}^{-}$ & $0.1619^{* * *}$ & 5.8736 \\
\hline$\Delta(D J I M)_{t-1}^{-}$ & $0.1607^{* * *}$ & 9.5346 & $\Delta(D J I M)_{t-1}^{-}$ & - & - \\
\hline$\Delta(D J I M)_{t-2}^{-}$ & - & - & $\Delta(D J I M)_{t-2}^{-}$ & $0.0387^{* * *}$ & 1.5072 \\
\hline$\Delta(D J I M)_{t-3}^{-}$ & - & - & $\Delta(D J I M)_{t-3}^{-}$ & - & - \\
\hline $\mathrm{R}^{2}$-adjusted & 0.1380 & & $\mathrm{R}^{2}$-adjusted & 0.1032 & \\
\hline Dependent value: $\Delta(D J G I)^{+}$ & & & Dependent $\mathrm{v}$ & & \\
\hline Constant & $-0.0011^{* * *}$ & -3.3751 & Constant & $0.0010^{* *}$ & 2.3790 \\
\hline$E C T_{t-1}$ & $-0.0008^{*}$ & -1.8981 & $E C T_{t-1}$ & $0.0014^{* *}$ & 2.5661 \\
\hline$W G B I_{t-1}$ & - & - & $W G B I_{t-1}$ & - & - \\
\hline$W G B I_{t-2}$ & $-0.0074^{* * *}$ & -2.8324 & $W G B I_{t-2}$ & - & - \\
\hline$W G B I_{t-3}$ & - & - & $W G B I_{t-3}$ & $0.0108^{* * *}$ & 3.2183 \\
\hline$\Delta O i l_{t-1}$ & - & - & $\Delta O i l_{t-1}$ & - & - \\
\hline$\Delta O i l_{t-2}$ & - & - & $\Delta O \mathrm{Oil}_{t-2}$ & - & - \\
\hline$\Delta \mathrm{Oil}_{t-3}$ & - & - & $\Delta \mathrm{Oil}_{t-3}$ & $0.0243^{* * *}$ & 3.8753 \\
\hline$V I X_{t-1}$ & - & - & $V I X_{t-1}$ & $-0.0001^{* * *}$ & -4.2331 \\
\hline$V I X_{t-2}$ & $0.0007^{* * *}$ & 3.4901 & $V I X_{t-2}$ & - & - \\
\hline$V I X_{t-3}$ & $-0.0006^{* * *}$ & -5.2992 & $V I X_{t-3}$ & - & - \\
\hline$U S E P U I_{t-1}$ & $0.0037^{* *}$ & 2.0188 & $U S E P U I_{t-1}$ & - & - \\
\hline$U S E P U I_{t-2}$ & - & - & $U S E P U I_{t-2}$ & - & - \\
\hline$U S E P U I_{t-3}$ & - & - & $U S E P U I_{t-3}$ & $-0.0151^{* * *}$ & -6.4478 \\
\hline$\Delta(D J I M)_{t-1}^{-}$ & $0.0756^{* * *}$ & 5.0525 & $\Delta(D J I M)_{t-1}^{-}$ & - & - \\
\hline$\Delta(D J I M)_{t-2}^{-}$ & $-0.0901^{* * *}$ & -4.4775 & $\Delta(D J I M)_{t-2}^{-}$ & $0.0765^{* * *}$ & 3.6200 \\
\hline$\Delta(D J I M)_{t-3}^{-}$ & - & - & $\Delta(D J I M)_{t-3}^{-}$ & $0.0858^{* * *}$ & 4.3620 \\
\hline$\Delta(D J G I)_{t-1}^{+}$ & - & - & $\Delta(D J G I)_{t-1}^{+}$ & - & - \\
\hline$\Delta(D J G I)_{t-2}^{+}$ & - & - & $\Delta(D J G I)_{t-2}^{+}$ & $-0.0851^{* * *}$ & -3.2580 \\
\hline$\Delta(D J G I)_{t-3}^{+}$ & - & - & $\Delta(D J G I)_{t-3}^{+}$ & & \\
\hline
\end{tabular}


Notes: DJGI and DJIM denote the Dow Jones Global and the Dow Jones Islamic Market indices respectively. ECT denotes the Error Correction Term. $\Delta(\bullet)$ is the first difference operator. The de-trended, scaled by 1000, 7/10-year World Government Bond Index is denoted by WGBI. Oil denotes the logarithmic change in the oil price. VIX is the implied volatility index as calculated by the Chicago Board Options Exchange (CBOE). US EPUI is the US Economic Policy Uncertainty Index, scaled by $1000 .{ }^{*},{ }^{* *},{ }^{* * *}$ denote statistical significance at the $10 \%, 5 \%$ and $1 \%$ levels respectively. - denotes a variable that the stepwise procedure dropped due to not being statistically significant at the minimum of $10 \%$. 
Table 7. Minimum Variance Portfolio Performance.

\begin{tabular}{|c|c|c|c|c|c|}
\hline Period & Strategy & W $_{\text {DJGI }}$ & $\mathbf{W}_{\text {DJIM }}$ & Return (\%) & $\begin{array}{r}\text { Annualized } \\
\text { Volatility (\%) }\end{array}$ \\
\hline \multirow{3}{*}{$\underset{\mathscr{E}}{\stackrel{D}{E}}-$} & S1 & 100 & - & -0.0631 & 17.4516 \\
\hline & S2 & - & 100 & -0.0748 & 26.3524 \\
\hline & S3 & 100 & - & -0.0631 & 17.4516 \\
\hline \multirow{3}{*}{ 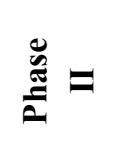 } & S1 & 100 & - & 0.0643 & 9.9073 \\
\hline & S2 & - & 100 & 0.0379 & 12.2392 \\
\hline & S3 & 97.1 & 2.9 & 0.0635 & 9.9050 \\
\hline \multirow{3}{*}{ 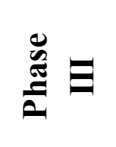 } & S1 & 100 & - & -0.0255 & 15.1895 \\
\hline & S2 & - & 100 & -0.0026 & 17.5248 \\
\hline & S3 & 87.8 & 12.2 & -0.0227 & 15.1398 \\
\hline \multirow{3}{*}{$\underset{E}{\stackrel{D}{E}} \geq$} & S1 & 100 & - & 0.0152 & 23.7378 \\
\hline & S2 & - & 100 & 0.0194 & 26.5813 \\
\hline & S3 & 91.6 & 8.4 & 0.0156 & 23.7120 \\
\hline \multirow{3}{*}{$\underset{\Xi}{\stackrel{D}{E}}>$} & S1 & 100 & - & 0.0428 & 14.2860 \\
\hline & S2 & - & 100 & 0.0631 & 16.0829 \\
\hline & S3 & 97.6 & 2.4 & 0.0432 & 14.2849 \\
\hline
\end{tabular}

Notes: Table reports the minimum variance portfolio weights, return and risk in each of the three investment strategies for every period. S1 denotes a pure conventional strategy; S2 denotes a pure Islamic strategy and S3 allows the investment in both Islamic and conventional equity indices. Annualized Volatility is measured as the average conditional volatility in each period. Conditional variances/covariances are estimated via a DCC-GARCH(1,1) model. The duration of the phases is outlined in section 7. 

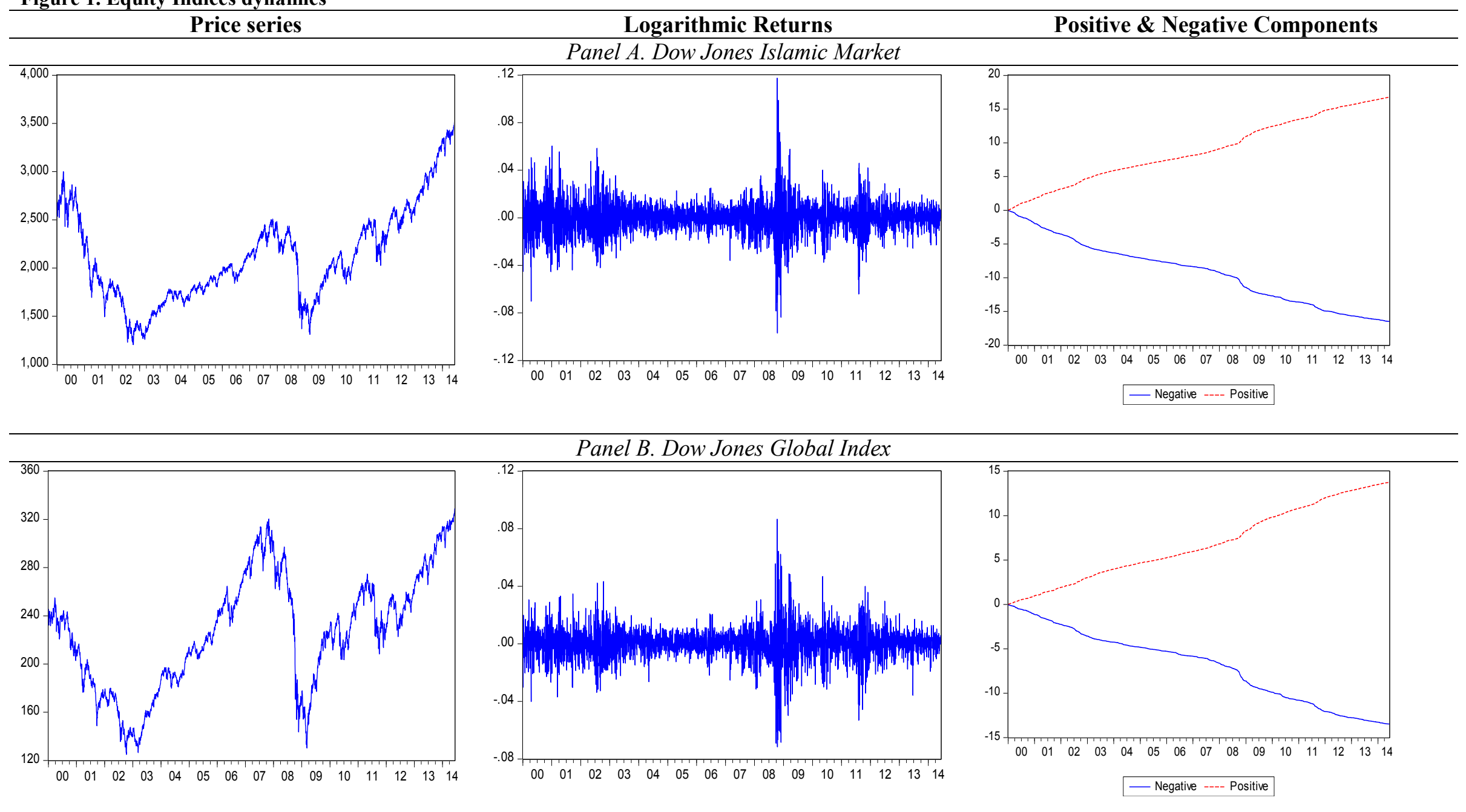